\title{
DOI https://doi.org/10.36059/978-966-397-241-1-5
}

\section{Замелюк М. I.}

кандидат педагогічних наук,

старший викладач кафедри теорії та методики дошкільної освіти Комунальний заклад вищої освіти «Луцький педагогічний коледж»

Волинської області

м. Луцьк

\section{ВИКОРИСТАННЯ ІННОВАЦІЙНИХ ПЕДАГОГІЧНИХ ТЕХНОЛОГІЙ У ВИКЛАДАННІ КУРСУ «ЕТНОПЕДАГОГІКА ДИТИНСТВА. СІМЕЙНА ПЕДАГОГІКА»}

Метою статті є узагальнення дослідження щодо доцільності використання інноваційних технологій у викладанні курсу «Етнопедагогіка дитинства. Сімейна педагогіка.». Дослідження дозволяє нам визначити потребу у формуванні у студентів системного уявлення про сім'ю як середовище розвитку і виховання; формування професійних вмінь педагога використовувати знання педагогіки сім'ї для аналізуії виховної функції та планування і організації педагогічної взаємодії вихователя закладу дошкільної освіти та сім'ї спрямованої на різнобічний розвиток дитини дошкільного віку.

Методологія. Опитування проводиться на основі порівняння даних респондентів (студентів факультету дошкільної освіти та музичного мистецтва) за допомогою анкети. Метою цього дослідження було дослідити якість викладання навчальної дисципліни, чи $\epsilon$ викладач новатором, яка ефективність інноваційних завдань на перевірку знань, умінь і навичок студентів, и цікаві завдання із самостійної роботи, чи цікавляться студенти тематичним наповненням професійного блоку дисципліни. І звичайно, погляд студента на вивчення дисципліни у ракурсі його бачення.

Результати опитування показали: студентам потрібний викладач новатор, який створює оптимальне онлайн чи оф лайн освітнє середовище. Успішна реалізація викладачем нових технології в своїй викладацькій роботі вимагає чітко спланованого, постійного професійного розвитку та підтримки. Зміна парадигми потрібна педагогам для ефективної інтеграції, мобільності, щоб залучати студентів до навчання, зокрема дисциплін професійного зростання. 
Просте володіння новими технологіями не гарантує ефективного використання студентами та педагогами в освітньому процесі. Педагоги повинні володіти інноваційними прийомами, техніками, технологіями, щоб спланувати креативну стратегію управління процесом пізнання студентами нового матеріалу та набуття ними професійного досвіду.

Таким чином, експериментальне дослідження показало багатовекторну особливість зв'язку читання дітьми та результатами їхнього розвитку.

\section{Вступ}

У зв'язку із вимогами та потребами сучасності у забезпеченні належних умов для формування особистості дітей дошкільного віку в сім'ї, реалізації та самореалізації iї природних можливостей спонукає до підвищення ефективності підготовки майбутніх вихователів до професійної діяльності та розкриває різнопланові аспекти підготовки сучасного сімейного вихователя. Ідеться насамперед про глибоку його психологічну та педагогічну підготовку, що дасть змогу вихователю самостійно, професійно здійснювати освітню роботу з дітьми дошкільного віку в домашніх умовах, науково-правильно розв'язувати як стандартні так i нестандартні педагогічні ситуації, створити дитині сприятливі умови для само актуалізації та формування творчої особистості.

Педагогічною наукою розроблені різні технології, види, форми та методи навчання, які зорієнтовані на оволодіння молоддю як теоретичним матеріалом, так і вміннями та навичками, необхідними до подальшої самостійної діяльності.

Аналіз досліджень із цієї проблематики (В. Кремень, І. Зязюн, С.Бараннікова, В. Загвязинский, М. Кларін, Г. Коджаспарова, В. Ляудіс, А.Моісєєв, І. Підласий, Л. Подимова, С. Поляков, А. Пригожін, В. Рибакова, В.Сластьонін, С. Сисоєва, П. Щедровицкий, А. Хуторской та ін.) дає можливість констатувати, що інноваційна педагогічна діяльність пов'язана з відмовою від усталених штампів, стереотипів у навчанні, вихованні та розвитку особистості.

Інноваційні процеси в освіті стали сьогодні невід'ємною частиною суспільного розвитку як головної вимоги часу. Нововведення стосуються мети, зміст, методи і форми навчання і виховання, організацію спільної діяльності суб'єктів освітнього процесу та ін.

Реалії сьогоднішнього дня такі, що для того, щоб бути успішним на ринку освітніх послуг, освітній установі необхідно ефективно 
реалізовувати інноваційну діяльність. А це зможе робити таке освітній заклад, в якому як адміністративна команда, так i педагогічний колектив розуміють суть інноваційної діяльності та готові нею займатися.
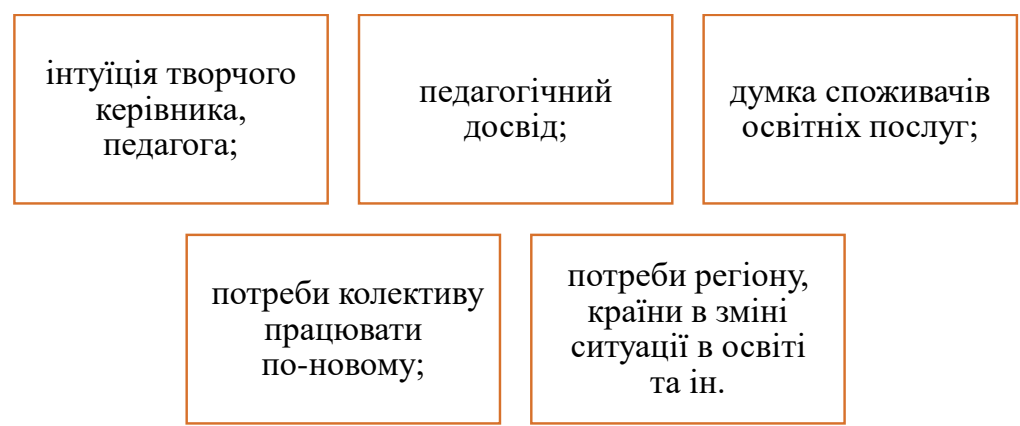

\section{Рис. 1. Джерела зародження інноваційних процесів}

\section{у практиці освітнього закладу}

Однак, повертаючись до теми проблем, що виникають у впровадженні інновацій в освіту, слід виділити наступний ряд можливих ускладнень. Однією з труднощів $є$ проблема вивчення, узагальнення i поширення сучасних педагогічних технологій. Педагог може виступати в якості учасника, розробника, дослідника, користувача i пропагандиста педагогічних інновацій. Проблема ж стосується впровадження досягнень інноваційних проектів в освіту на практиці.

у більшості випадків освітні організації, педагогічний склад i навіть самі навчаються виявитися не готовими як до сприйняття нового в освітньому процесі, так і до послідовної діяльності у впровадженні інновації.

Інноваційні технології в освіті впроваджуються 3 певними ускладненнями з різних причин:

- бар'єр творчості (педагоги, які звикли працювати за «старими» програмами, не хочуть щось змінювати, вчитися, розвиватися);

- конформізм (педагоги відмовляються приймати незвичайні педагогічні рішення);

- особистісна тривожність (невпевненість у собі, в своїх здібностях, занижена самооцінка, страх висловлювати відкрито свої судження);

- $\quad$ ригідність мислення (з певних причин вважають свою думку єдиною, остаточною та не визнають компроміси) [1]. 


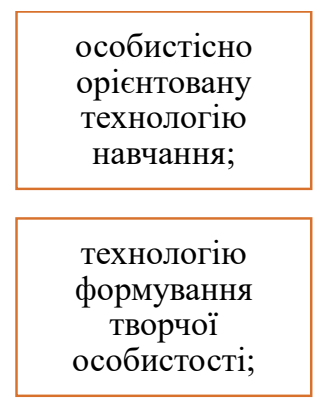

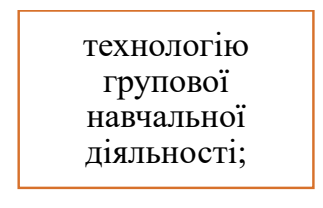
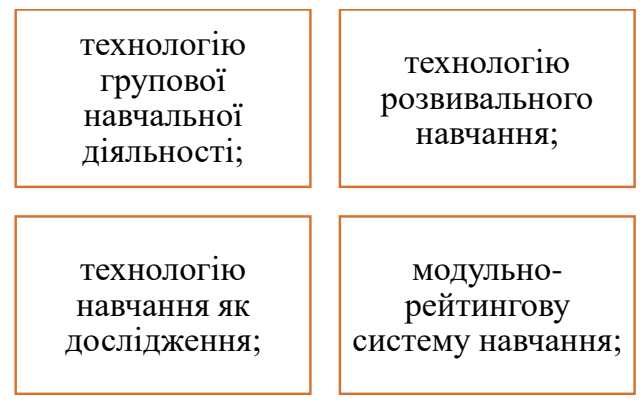

нові інформаційні технології (НIT) та комп'ютерне навчання тощо.

Рис. 2. Інноваційні технології

\section{1. Можливість застосування зазначених технологій на лекційних заняттях}

У підготовці фахівців спеціальності 012 Дошкільної освіти викладачі стикаються з проблемою: як підготувати фахівця «нового формату» для роботи з «новими дітьми», педагоги, усвідомлено підходить до вирішення професійних завдань. Однак, виникає необхідність перегляду змісту освіти, внесення змін в модель навчання. Однією з сучасних педагогічних технологій $є$ Технологія розвитку критичного мислення.

Термін «критичне мислення» отримав свою популярність в дослідницьких колах після обгрунтованого К. Поппером філософського напряму «критичний реалізм». Згідно з його теорією про всяк живий організм діє як вирішувач проблем. При цьому дані 3 навколишнього світу використовуються для підтвердження або спростування гіпотез, які живий організм попередньо задає [2].

Науковці (Р. Пауль, В. Руджеро, М.Скривен, С.Терно, Н. Туласинова, 0. Тягло, Д. Халперн, П. Фачоне) визначають критичне мислення як здатність сприймати і переробляти інформацію в точки зору логіки, при цьому застосовуючи результати в стандартних і нестандартних ситуаціях.

Зокрема, Загашев I. визначає критичне мислення як сукупність якостей і умінь, що обумовлюють високий рівень дослідницької культури студента та викладача, а також «мислення оцінне, 
рефлексивне», для якого знання $є$ не кінцевою, а відправною точкою, аргументоване і логічне мислення, яке базується на особистому досвіді та перевірених фактах [3].

Таким чином, даний тип мислення допомагає людині визначити власні пріоритети в особистому та професійному житті; передбачає прийняття індивідуальної відповідальності за зроблений вибір; підвищує рівень індивідуальної культури роботи з інформацією.

Д. Халперн виділяє наступні характеристики, властиві критично мислячій людині. Критичні мислителі вміють вирішувати проблеми і виявляють відому наполегливість в їх вирішенні, контролюють емоційно-вольові процеси, свою імпульсивність, вміють слухати співрозмовника, вміють вирішувати проблеми, співпрацюючи 3 іншими людьми, виявляють емпатію. Дослідник відзначає, що найбільш сильними характеристиками їх особистості є відкритість для будь-яких ідей і нетерпимість до невизначеності. Це дозволяє їм відступати від шаблонів, розширювати межі реальності i встановлювати множинні зв'язки між явищами. Уміння терпимо ставитися до різних точок зору робить їх більш культурними та продуктивними в груповій роботі [4].

Вищезазначене дає підстави зробити узагальнення, що критичне мислення в контексті інноваційної діяльності передбачає сформованість раціональних здібностей.
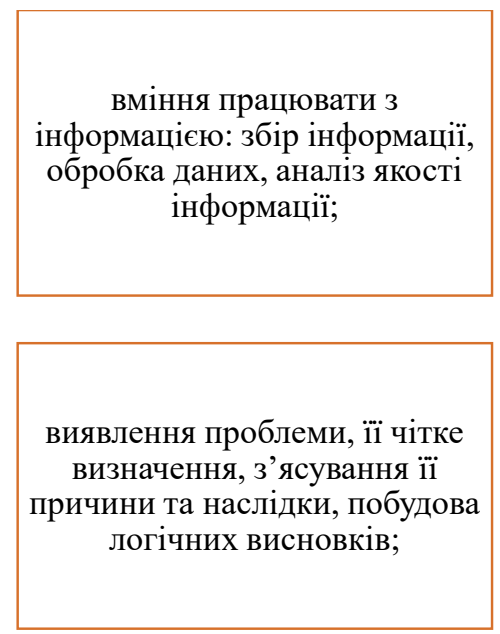

розгляд ситуації (навчального завдання, проблеми) в цілому, виділення головного й другорядного;

Рис. 3. Сформованість раціональних здібностей [5, с. 34-38] 
При викладанні курсу технологія критичного мислення реалізується в рамках практичного оволодіння студентами навчальним матеріалом у підготовці до самостійної роботи.
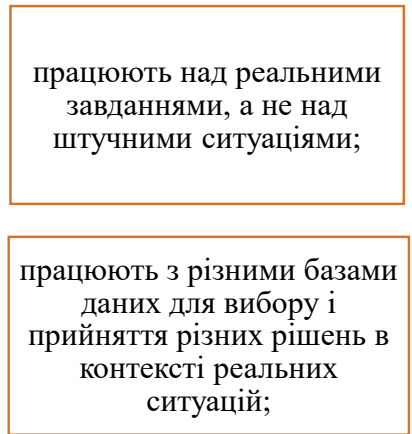
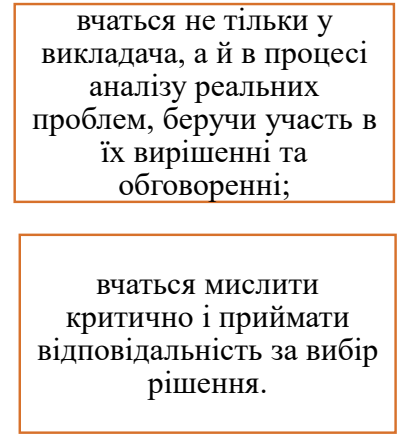

\section{Рис. 4. Показники навчальної моделі оволодіння студентами матеріалом курсу}

Зокрема, викладач під час викладання курсу створює проблемні ситуації, використовує матеріали, що демонструють принципи критичного мислення, застосовує при цьому методи навчання, які надають можливість вибору, діалогічність відносин в спілкуванні та демократичному стилі проходження навчальної дисципліни.
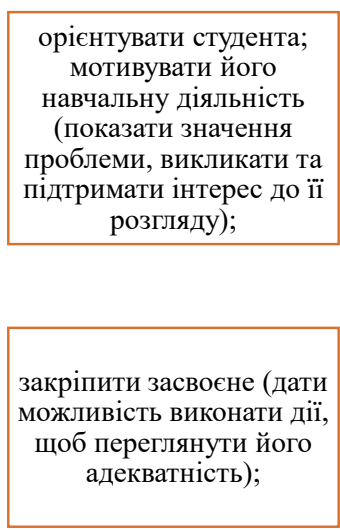

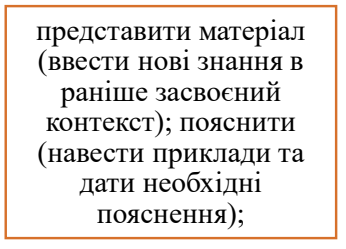

обговорити рішення, його відповідність ситуації;

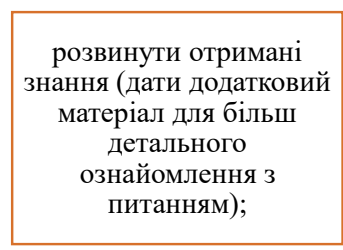

сприяти розвитку не тільки інтелектуальних, але і моральних якостей (розвиток характеру, професійної етики, поваги до себе та іншими, виховання соціальної відповідальності)

Рис. 5. Завдання викладача у формуванні критичного мислення 
Таким чином, дана технологія $є$ системою стратегій і методичних прийомів, призначених для використання в різних видах і формах роботи.

Запорука успішної, продуктивної бесіди або лекції є стійкий контакт з аудиторією і компетентністю у даній сфері.

Таке поєднання не перетворює лекцію в монолог, а замість цього робить ії цікавим процесом, у якій група з готовністю включається в освітній матеріал. Педагогу важливо визначити заздалегідь кордони тієї інформації, яку повинна знати група. Зробити це не так легко, як може здатися на перший погляд. Тому викладач знаходить ті межі, де ці інтереси перетинаються, і проводить тренінг у такому стилі, який максимально задовольняє ці вимоги.

Студенти охоче навчаються тільки тоді, коли вони впевнені, що їм це вигідно (вони не є суто матеріальними, але включають у себе перспективи кар'єрного росту, підвищення ступеня задоволеності роботою і визнання з боку оточуючих). Тому, дуже важливо надати їм таку мотивацію, чітко продемонструвавши переваги, які отримують учасники тренінгу. Навіть якщо учасники тренінгу відчувають сильну потребу в навчанні і мають високу мотивацію, вони ніколи не навчаться тому, чого вони не розуміють.

Перевірка рівня знань містить два елементи, які тренер повинен прийняти до уваги.

По-перше, він повинен бути здатний оцінити рівень знань всередині групи. Хто є її учасниками - зацікавлені новачки або люди, авторитетні у своїй сфері діяльності? Визначивши це, тренер зрозуміє, який рівень складності повинна мати лекція (рівень буде занадто низьким, тренер ризикує викликати поблажливе ставлення аудиторії і остаточно позбутися її уваги в подальшому; якщо тренер прорахує і зробить курс занадто просунутим, то він, швидше за все, вселить в учасників відчуття невпевненості, роз'єднає групу та посіє нудьгу).

Таким чином, знайти золоту середину нелегко. Однак, тренер повинен врахувати особливості сприйняття і розуміння групи. По можливості слід уникати використання жаргонних і професійних виразів. У ситуаціях, коли спеціальні терміни необхідні, слід доступно пояснювати їх значення. При цьому пам'ятаючи, що завдання тренінгу полягає в удосконаленні знань учасників групи, а не зниження їх самооцінки, викликане тим, що вони чогось не розуміють. 


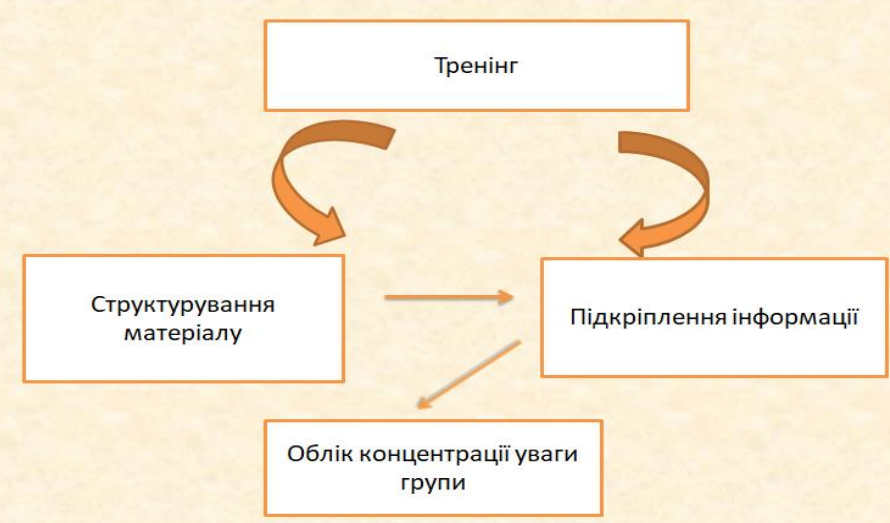

\section{Рис. 6. Способи поліпшення сприйняття і засвоєння інформації учасниками тренінгу}

Детально розглянемо ці способи.

Структурування матеріалу. Час, витрачений на підготовку до занять, ніколи не пропадає даремно. Кілька хвилин, використаних для структурування лекційного матеріалу, можуть значно поліпшити збереження отриманої інформації у пам'яті учасників. Лекційний курс повинен будуватися послідовно, щоб бути зрозумілим кожному. Коли інформація, представлена в ньому, складна, тренер повинен передавати ії групі поступово, обдумуючи кожен крок, Якщо треба підкріпити матеріал додатковими відомостями, треба розглянути історичні передумови досліджуваної теми. Щоб інформація краще засвоюється, треба розбити її на кілька частин.

Підкріплення інформації. Треба розповісти групі про тему лекції. Викласти запланований матеріал. Повторити ключові моменти лекції. Це повторення буде виправданим. Воно допоможе прояснити і ще раз підкреслити основні пункти лекції.

Облік концентрації уваги групи. Викладати інформацію треба 3 урахуванням обмежень, що накладаються особливостями групового уваги. За усталеній думці, оптимальний період концентрації уваги становить 20 хвилин, але іноді його можна збільшити до 40 хвилин за допомогою зміни стилю, темпу або манери підношення інформації. Прикладом цього може бути пауза при викладі матеріалу, зроблена для відповідей на питання або для поширення роздаткового матеріалу й знайомства з ним [6]. 
Зокрема, при викладанні лекцій курсу «Етнопедагогіка дитинства. Сімейна педагогіка.» у розпорядженні тренера $\epsilon$ безліч способів подачі матеріалу. При цьому студенти мають змогу навчитися працювати в одній команді, групами, вирішувати завдання різними методами та способами.

У розвитку особистості дитини головним джерелом соціалізації $\epsilon$ сім'я, в ній людина засвоює норми та правила людської поведінки. У сім'ї людські переконання, цінності, ідеали перетворюються в особистісні якості, формують подальші життєві рішення і поведінку.

На даний час зросла кількість сімей, соціальне функціонування яких з суб'єктивних чи об'єктивних причин порушено або утруднене, а існування усієї сімейної структури знаходиться під загрозою. Це сім'ї соціального ризику, які потребують особливої соціальної допомоги, великої уваги держави, педагогів, так як вони не в змозі самостійно впоратися з проблемами.

Одним з головних генераторів роботи з проблемами сім'ї можуть і повинні стати соціальні інновації, націлені на гармонійне, збалансований розвиток сім'ї і суспільства.

Проблеми технологізації соціального простору на даний час стають все більш актуальними. Існує дві форми інноваційних технологій. До першої форми відносяться різні програми та документи. Другою формою $є$ соціальні процеси, які формуються у взаємозв'язку з даними програмами.

Розглянемо метод «Соціально-освітній ліфт», що виступає одним 3 інноваційних у роботі з сім'єю, сенс якого полягає в тому, що однією 3 ключових для нашого суспільства проблем $\epsilon$ відсутність можливостей для зміни соціального шару, тобто соціальної мобільності в суспільстві. Що несе у собі поліпшення ефективності роботи з сім'ями, а також підтримка неблагополучних сімей.

Наступним інноваційним методом $\epsilon$ «Робота 3 мережею соціальних контактів». Він заснований на зарубіжному методі роботи $з$ соціально неблагополучними сім'ями через установку подальшого контакту з сім'єю. Мережевий метод полягає в допомозі фахівців соціальних служб сім'ям, у яких порушуються або зруйнувалися зв'язки з соціальними інститутами, причому сім'я не може відновити ці зв'язки без кваліфікованої допомоги.

Найголовнішим завданням технології «Інтенсивна сімейна терапія» $€$ продуктивне застосування внутрішнього потенціалу сім'ї і кожної ії особистості для вирішення важких життєвих проблем і зміцнення сімейних відносин. Здійснення даної технології 
реалізується через роботу фахівців соціальних служб, а також через розробку спеціальних програм реабілітації сімей і її членів.

У наданні допомоги сім'ї психолого-педагогічна робота відіграє важливу роль, зміцнюючи все громадянське суспільство і формуючи єдиний реабілітаційний простір для сімей, які перебувають у важкій життєвій ситуації. Для вирішення проблем даної категорії сімей можна надавати психолого-педагогічне консультування, посередництво в конфлікті, організація груп само- і взаємодопомоги та ін.; сприяння навчанню і розвитку дитини в сім'ї.

До основних функцій сім'ї відносяться репродуктивна, виховна, соціальна, економічна, соціально-статусна та ін. Держава й суспільство взаємодіють з сім'єю, а також безпосередньо впливають один на одного, відповідно зацікавлені в благополуччі сім'ї. Порушення сімейної структури може привести до руйнування функцій сім'ї. Негативна психологічна атмосфера в сім'ї стає наслідком психічної напруженості, сварок, депресій, сімейного насильства [7, с. 58-61.]. При відсутності прагнення членів сім'ї змінити таке становище, саме існування сім'ї опиняється під загрозою.

У всі часи та й у всіх суспільствах були люди, що відрізняються надзвичайною удачливістю, ті, у кого будь-яку справу спирається, а будь-які умови складаються найбільш сприятливим чином. Ніби весь світ підпорядкований єдиному завданню: надавати допомогу щасливчикам в усьому, за що б вони не бралися. У сучасному світі успіхи таких людей яскраві і помітні, в бізнесі вони $\epsilon$ тими самими «Золотниками», які приносять удачу будь-якому підприємству. Вони ж $є$ тими героями, на яких прагнуть бути схожими мільйони простих людей.

Тому не випадково у всіх засобах масової інформації ми чуємо слова «успіх», «успішність», складаються рейтинги успішних людей, нав'язується певний образ успішної людини. Створено незліченну кількість тренінгів, які обіцяють допомогти людям стати успішними. Але ніхто не каже, що ж це таке успішність особистості, які її ознаки та критерії.

Безумовно, $є$ якісь зовнішні ознаки успішної людини. Це, як правило, офіційне визнання, звання, премії, нагороди, матеріальні блага. Але видається, що $є$ ще один пласт розуміння успішності, який у сучасному суспільстві набуває більш важливе значення. Не зважати на нього, а тим більше не помічати, в сучасних умовах, вже не можна.

Ідеали, нав'язуванні сьогодні рекламою і 3MI, формують так зване «суспільство споживання». Вони спрямовані на стимулювання 
непотрібних покупок і витрат, а в кінцевому підсумку, погоні за престижем i «актуальним» іміджом. Бездумне дотримання цих «ідеалам» веде до глибокої внутрішньої кризи, так як рано чи пізно людина усвідомлює, що все своє життя вона витратила не на розкриття свого потенціалу та реалізацію своїх власних потреб, а на досягнення якогось примарного ідеалу «успішної» життя. Це не кращим чином позначається на її роботі. Адже в роботу людина вносить всі свої особливості, здібності, програми та внутрішні конфлікти. І якщо цих конфліктів немає, то людина має можливість реалізувати свій творчий хист швидше та ефективніше. Як відомо, саме реалізація талантів громадян рухає суспільство дорогою прогресу в науці, бізнесі, мистецтві, педагогіці та й в інших сферах. А людина, що реалізувала таланти та задовольнила свої потреби, $\epsilon$ успішною людиною.

Більшість батьків хочуть виховати успішну дитину. Очевидно, що успіх не можна подарувати. Батьки можуть забезпечити фінансами та іншими матеріальними благами, але просто так дати своїй дитині успіх ніхто не зможе. Звичайно, стартові можливості у кожної дитини різні. Але скільки життєвих прикладів доводять нам, що без певних якостей особистості та рис характеру, бути успішним не вийде.

Педагоги та батьки бачать вже в дитині особистість. Вміють домовлятися 3 дитиною, відчувають її настрій і потреби. Дитина повинна відчувати свою значимість в житті сім'ї, бачити любов і ласку. У неї $\epsilon$ певні обов'язки, умови для самостійного прийняття рішення. Допомога дорослим приносить радість і задоволення. Позитивне спілкування дорослого з дитиною відбувається на довірчій основі. Така дитина виростає самостійною особою. та знає, що таке любов до себе, до батьків, не боїться завести необхідні для неї знайомства. поважає своїх близьких, родичів, друзів, працьовита. 3 позиції сучасної психології щастя, успіх, авторитет $є$ побічними продуктами правильно організованого життя.

Безумовно, для роботи над проблемами в сім'ї вихованця та підготовки вихователя до роботи з ними, необхідний час і зусилля. Але одним 3 основних критеріїв продуктивності інноваційної діяльності слід вважати моральну і психологічну готовність майбутнього вихователя до сприйняття змін усталених патернів педагогічної поведінки. Саме відкритість новому буде сприяти вирішенню ряду проблем. Виклад лекційного матеріалу методом тренінгів проходять в науковому співтоваристві змін. Перелом в так 
званому ригідному мисленні приведе до набуттям студентами тієї необхідної для інноваційної діяльності та відкритості.

Таким чином, формування готовності майбутніх вихователів до інноваційної діяльності повинна бути націлена на формування таких особистісних особливостей, як відкритість новому, творчому та креативному мисленні.

Інтерактивне обладнання допомагає перетворити освітній процес в ігрову діяльність, так як гра більш приваблива для сприйняття інформації особистістю. У студента підвищується мотивація для пізнання і розкриття творчих здібностей.

Лекційна форма роботи засобами рольової гри дозволяє контролювати час заняття. Не завжди можливо оцінити, скільки часу займе та чи інша сесія запитань і відповідей, але можна 3 великою точністю підрахувати, скільки часу триватиме вся лекція.

Для того щоб отримати максимальну користь від рольової гри, запропоновані ситуації повинні бути якомога ближчими до реальності. Необхідно виділити час для підготовки стислого опису задіяних персонажів і упевнитися, що створювані умови гри максимально відповідають специфіці основної діяльності учасників. Інструкція до рольової гри повинна детально описувати всі аспекти ситуації. Разом 3 тим, ця інструкція не повинна ставити жорстких кордонів, що перешкоджають учасникам зіграти свої ролі відповідно до їх власними уявленнями про те, як необхідно діяти в таких випадках,

Завданнями, до вирішення якої прагнуть члени групи, які беруть участь у рольовій грі, виступають: створення моделі поведінки, характерного в повсякденному житті для реальних людей. Саме поведінка, а не прояву талантів виступаючих буде основою подальшої дискусії. Група повинна спостерігати за змістом кожної розігрується сцени. Тим, хто не бере участі в грі, слід запропонувати зайняти ролі спостерігачів і записувати особливості поведінки учасників і його наслідки.

Спостереження може стати ще більш корисним, якщо зробити відеозапис рольової гри та в разі необхідності використовувати їі для забезпечення зворотного зв'язку.

Як зробити заняття живим, цікавим і корисним? Як зберегти «дух мудрості» та передати його новому молодому поколінню? Як зробити процес навчання таким, щоб студент щодня виходячи зі стін закладу вищої освіти міг сказати, що сьогодні дізнався багато нового та корисного? Як зробити так, щоб студент і викладач отримували задоволення від їхньої взаємодії і спілкування? Як зробити так, щоб студент як майбутній фахівець відповідав сучасним реаліям часу, був готовий вирішувати нові професійні завдання? 

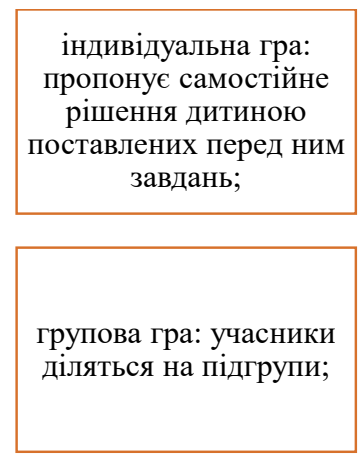

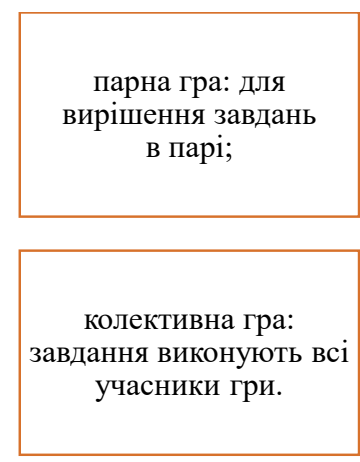

Рис. 7. Форми інтерактивної гри [8]

Один $з$ підходів до вирішення поставлених запитань доволі простий, активне використання інновацій у навчанні, іншими словами, інноваційних методів навчання як нової зброї педагога.

3 одного боку інновації змінюють методи роботи педагога, саме взаємодія, взаємини викладача і студента, 3 іншого - інновації змінюють мислення педагога, стають філософією практичної діяльності як викладачів, так і студентів.

\section{2. Можливість застосування зазначених технологій на практичних заняттях}

Нові методи навчання - це образно кажучи «багатофункціональна зброя» педагога, що вимагає майстерно ним володіти та модифікувати.

Зокрема, у процесі роботи 3 методом «Сократичний діалог» студенти формулюють управлінську проблему та розбирають альтернативні підходи. Студенти та викладач, стоячи на різних позиціях, уточнюють в суперечці свої позиції. В ході заняття викладач ставить запитання студентам і просить висловити своє ставлення до управлінської проблеми (в сфері освіти).

Таким чином, даний метод формує уміння відстоювати свою точку зору, публічно особисто її висловлювати, вміння слухати, розвиває мислення.

Техніка методу «Дерево рішень» використовується для раціоналізації процесу прийняття рішень в ситуації, коли неможливо дати просту однозначну відповідь на поставлене завдання. Формує уміння знаходити помилки. Методика використовується при аналізі ситуації і допомагає досягти повного 
розуміння ії причин. Учасники детально аналізують всі можливі варіанти рішень і виписують в колонки переваги та недоліки кожного з них, наслідки. В ході обговорення учасники заповнюють таблицю: Даний метод дає можливість студентам проявляти готовність до перегляду своїх суджень і зміни образу дій в світлі суттєвих переконань

Цікавим для практичного опрацювання тем 3 курсу $є$ метод «Ланцюжок».

Студентам дається завдання розкрити проблему 3 наступних запитань, відповідаючи по порядку за створеним ланцюжком «Хто?», «Що?», «Де?», «Коли?», «Як?», «Навіщо», «Чому?» Залежно від теми викладач варіює, додає питання самостійно. Разом 3 тим ми формуємо у студента уміння описувати ситуацію, вміння виділяти головне,

Для роботи над темою «Сім'я очима дитини» доречно використовувати метод «Колаж» (обирається тема, пропонується заздалегідь принести вирізки з

газет і журналів з яскравими картинками (додатково ножиці, клей і ватман), що стосуються цієї теми, студентам пропонується висловити тему змісту за допомогою наклеєних картинок на ватмані. Умова: без слів, за бажанням студенти наклеюють на ватман картинки, після закінчення роботи, розповісти, як вони розуміють поняття, наприклад, «Сім'я» (або відповідають іншій команді, який зміст вони бачать на ватмані). За допомогою такого методу розвиваються уміння варіювати основними поняттями етнопедагогіки та застосовувати їх при виконанні теоретичних і практичних завдань, добирати приклади педагогічних ситуацій з сімейного виховання, що зорієнтовані на формуванні гуманістичних почуттів особистості, міркувати, розуміти,

Метод «Кількість. Якість. Ідея» характеризується: кількістю ідей розв'язання будь-якої проблеми; якістю найбільш оптимальних рішень завдання; ідейністю реальних, оригінальних ідей.

Таким чином, даний метод формує у студентів уміння приймати рішення, уміння відбирати найбільш оптимальне, інтегроване, практичне.

Метод придумування - це спосіб створення студентами невідомого раніше продукту в результаті їхніх певних розумових дій. Метод реалізується за допомогою наступних прийомів: заміщення якостей одного об'єкта якостями іншого з метою створення нового об'єкта; відшукування властивостей об'єкта в іншому середовищі; 
зміна елемента досліджуваного об'єкта та опис властивостей нового, зміненого об'єкта.

На заняттях студенти освоюють необхідні навички, через застосування таких методів і прийомів, які стимулюють пізнавальну активність студентів. Студент вступає в діалог 3 викладачем, одногрупниками, виконує творчі завдання. Основними методами і прийомами роботи за такого навчання $\epsilon$ самостійна пошукова робота, проблемні та творчі завдання. Зокрема, метод веселки дозволяє барвою кольорів критично мислити, ключові компетентності, творчу особистість, створювати ситуації успіху.

Сучасна парадигма освіти, вік інформації та інформаційних технологій, науково-технічний прогрес, відкритість суспільства зажадали введення в ключові компетенції професійної освіти когнітивної компетенції студента.

Характеристика когнітивної компетенції включає готовність до постійного підвищення свого освітнього рівня, потребу в актуалізації та реалізації особистісного потенціалу, здатність самостійно здобувати нові знання i вміння, прагнення до саморозвитку, постійному збагаченню своєї професійної компетентності. Відштовхуючись від розуміння когнітивної сфери як сфери психіки людини, пов'язаної з пізнавальними процесами, акцент у формуванні когнітивної компетентності ми робимо на розвиток пізнавальних умінь і навичок, які органічно пов'язані із саморозвитком. Зокрема, когнітивна компетентність пов'язана 3 умінням структурувати інформаційний матеріал і знання, вміти робити їх візуальне уявлення, знаходити нові візуальні продуктивні рішення, вміння презентувати та робити доступними їх для інших людей. таке розуміння частини компонентів когнітивної компетентності пов'язане 3 візуальною культурою майбутнього фахівця.

Візуальна культура важлива для педагога як для розробки наочних навчальних посібників, так і для побудови композицій занять, предметів тощо. 3 іншого боку, активність настання візуальних засобів (екранна культура, реклама та телебачення та ін.), що роблять візуальну культуру інструментом професійної діяльності в багатьох професіях. Як формувати візуальну культуру у майбутніх фахівців для вдосконалення пізнавальної діяльності людини?

Структура візуальних рішень може бути: лінійною та розгалуженою (мережевою), індуктивною і дедуктивною і ін. В той же час саме рішення може бути і не структурним, а образним 
(найбільш часто використовувані: дерево, піраміда, годинник, сходи та ін.). Для студентів також пропонується метод інтелект-карт, розроблений Т. і Б. Бьюзен [9, с. 219].

Метод інтелект-карт - це графічне вираження процесу мислення. Структурування матеріалу відбувається у вигляді «восьми ніжки».
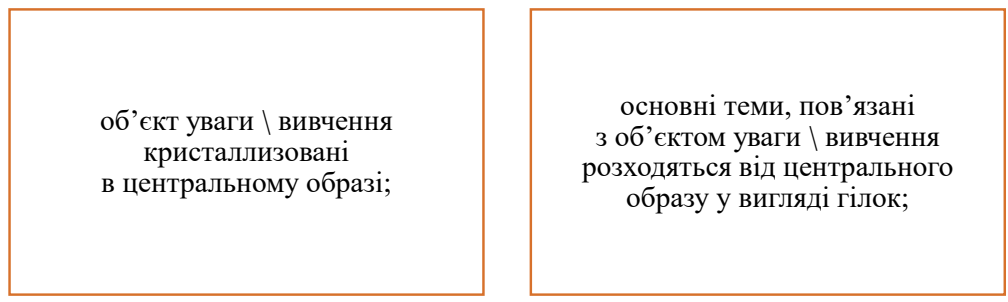

гілки, що приймають форму

плавних ліній, позначаються і пояснюються ключовими словами або образами. Вторинні ідеї також зображуються у вигляді гілок, що відходять від гілок вищого порядку.

Те ж справедливо для теоретичних гілок;

\section{Рис. 8. Відмінні риси інтелект-карт}

Якість інтелект-карт можна поліпшити за допомогою кольору, малюнків,

закодованих виразів (наприклад, відомих абревіатур), а також за допомогою додання карті тривимірної глибини.

Наприклад, для студентів пропонувалося завдання: розробити інтелект карту основних положень щодо виховання та навчання дитини в сім'ї (ознайомитися з реалізацією ідей всебічного розвитку особистості в гувернерських виховних системах (на вибір студента) та створити інтелект карту за цим матеріалом).

Для роботи над темою «Підготовка дитини до вступу в заклад дошкільної освіти» для студентів пропонувалося скласти авторську казку дитині про те, як ходити в дитячий садок: Великий вплив авторської казки можна прослідкувати на прояви емоційності, уяви, творчості особистості. В процесі виконання завдання студенти розкривали свою творчу активність. Авторська казка створювала 
умови для особистісно-професійної самореалізації, творчої індивідуальності кожного майбутнього вихователя.
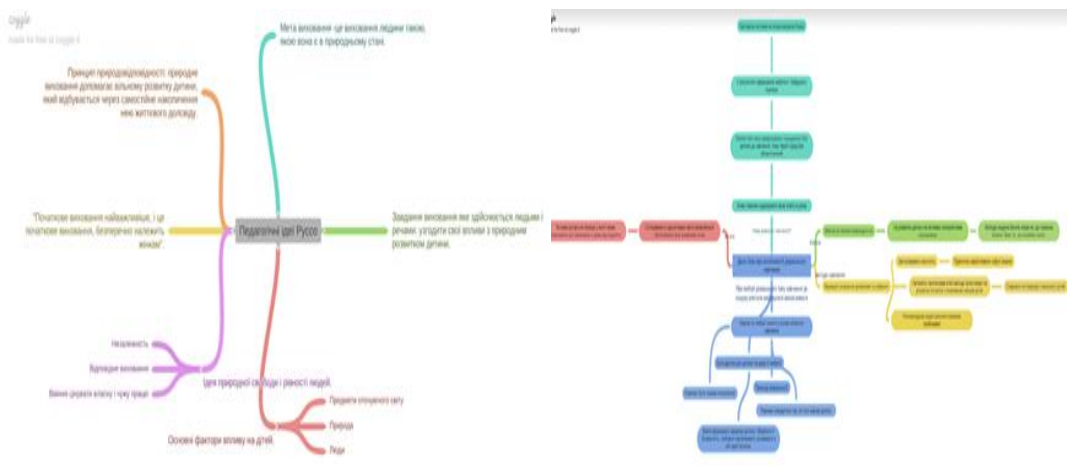

\section{Рис. 9. Приклади інтелект карт}

Серед засобів формування творчої особистості майбутнього вихователя виокремлюємо, зокрема, такі, як: інтелектуальні ігри, інтелектуальні конкурси, авторська казка, казкотворчість, казкотерапія.

Особливий пріоритет мають інтелектуальні ігри. На відміну від предметних олімпіад, наукових конференцій, різноманітних факультативів, ігри дозволяють перетворити серйозну інтелектуально-творчу діяльність на яскраве видовище, захоплююче змагання, свято.

Основною метою проведення таких ігор («Що? Де? Коли?», «Своя гра», «Ерудит-квартет», «Трійка») $є$ розвиток у студентів творчих здібностей, розкриття інтелектуального потенціалу та виявлення нових талантів. Участь студентів у змаганнях різного виду дозволяє розширити свій кругозір, практично застосувати власні знання, ерудицію і логічне мислення, проявити вміння приймати рішення в нестандартній ситуації в умовах обмеженого часу.

Ігрова технологія загалом дає можливість значною мірою посилити виховний процес, який визначається тими сприятливими обставинами, в яких опиняються її учасники - гравці. Гра створює чудову можливість для активного міжособистісного впливу, оскільки грати - значить вступати у взаємодію з партнерами, гра - це свого роду полігон для громадського та творчого самопізнання (В. Беспалько). 
Інтелектуальні конкурси (конкурс студентських наукових робіт, брейн-ринг тощо, розглядається як майданчик особистісного самовираження студентів, що дозволяє максимально проявляти свої здібності, перевіряти якість своїх знань, а педагогам - створювати умови для виявлення, розвитку і підтримки обдарованих студентів, формування конкурентоздатної особистості.

Провідним засобом розвитку творчості особистості на нашу думку, є авторська казка, казкотворчість. При цьому ми виходимо 3 того, що казкотворчість - це розкодування знань про світ і взаємини в ньому; процес пошуку смислу і мети життя, істинних цінностей та орієнтирів; активація ресурсного потенціалу й потреби самоактуалізації особистості майбутнього вихователя.

Предметом казкотворчості, як стверджує Т.Зінкевич-Євстігнеєва, $\epsilon$ процес пробудження внутрішнього «Я», його виховання, розвиток душі. Основним завданням $є$ внутрішня перемога «Я» і як наслідок, перемога людини в реальному житті на основі набутих досвіду і знань. Метою казкотворчого спілкування є досягнення внутрішньої гармонії, актуалізація потреби самопізнання i самотрансценденція [10].

Казка $є$ закодованою системою знань для душі і особистості, що відбувається в казкових подіях із сфер чистого духу. Можливості різноманітніх технік казкотворчості суттєві. Вони формують «моральний імунітет» людини; активують діяльність обох півкуль мозку і відповідних генетичних рівнів; розширюють можливості трансцендентного і екзистенціального (за українським тлумачним словником- пов'язаний із буттям, існуванням людини) самопізнання; вдосконалюють майстерність духотворчості через розвиток енергопотенціалу, чуттєвості, психомоторики, мислення й уяви; забезпечують гармонійний розвиток особистості, душі і духу, що на певному життєвому етапі проявляється мовою казки.

Відтак, на допомогу приходить авторська казка, що метафорично описує реальні події, переживання і мрії. Якщо вона закінчена та має позитивний творчий аспект, своєрідну програму, що притягує можливості, ситуації, людей для іï реалізації' - вона здійснюється.

Таким чином, у практиці казкотворчості значне місце займають проективні методики, оскільки в них одночасно представлені і образ, і відношення до світу, і особистий досвід переживання. Цілісне сприйняття «внутрішнього світу» людини дозволяє розкрити зміст iіi ресурсів - того творчого потенціалу, який формує перспективні завдання психологічної роботи через вирішення іï актуальних 
проблем. Особливу роль відіграють нетрадиційні знання, які використовуються для актуалізації певних психологічних феноменів і свідомого моделювання ситуацій або майбутнього.

Розвиток системи освіти, популярність і актуалізація вищої освіти пред'являють підвищені вимоги до якості підготовки дипломованих фахівців. Від сучасного закладу вищої освіти потрібно впровадження передових технологій навчання, що забезпечують поряд 3 його фундаментальністю розвиток комунікативних, творчих i професійних компетенцій, потреб в самоосвіті на основі потенційної багатоваріантності змісту та організації освітнього процесу, що можливо за рахунок застосування інноваційних педагогічних технологій.

Дистанційне навчання, засноване на використанні дистанційних освітніх технологій за допомогою мережі Інтернет, будучи чимось особливим у відношенні до сучасній освіті, стає логічним розвитком сучасної освіти, яке традиційно переважно здійснюється в просторі аудиторії.

Дистанційне навчання має ряд принципів, які $є$ характерними саме для цієї форми навчання:

- принцип інтерактивності. Даний принцип заснований на тому, що в процесі навчання студенти та педагоги між собою спілкуються за допомогою інформаційних і телекомунікаційних технологій.

- принцип стартових знань. Для того, щоб процес дистанційного навчання був ефективним кожен студент повинен мати початковий рівень підготовки в плані роботи з ПК та іншим технічним забезпеченням, а також навичками роботи в мережі Інтернет.

- принцип індивідуалізації. Даний принцип передбачає, що темп освітнього процесу, час проведення занять, визначається кожним студентом самостійно, виходячи зі своїх можливостей i потреб. У процесі освоєння навчального матеріалу, можливе корегування індивідуального плану, за підсумками контрольних зрізів.

- $\quad$ принцип ідентифікації. Даний принцип на сьогоднішній день $\epsilon$ найбільш актуальним, так як дистанційне навчання надає більше можливостей для фальсифікації (виконання завдань іншою людиною). Саме тому багато сил з боку дистанційного освітнього закладу направлено на здійснення контролю самостійності навчання студентами. 
- принцип регламентного навчання. Даний принцип заснований на тому, що дистанційне навчання для його оптимізації повинно здійснюватися на підставі суворого регламенту часу освоєння дисциплін, шляхом введення графіка самостійної роботи.

- принцип педагогічної доцільності застосування засобів нових інформаційних технологій. Даний принцип $\epsilon$ провідним педагогічним принципом дистанційного навчання. Незважаючи на те що процес дистанційного навчання передбачає використання інноваційних технологій і засобів, використання їх повинно бути в рамках розумності та доцільності.

- принцип забезпечення відкритості і гнучкості навчання. Даний принцип дистанційного навчання означає, що на сьогоднішній день дистанційне навчання відкрите та доступне практично для всіх людей без обмежень за віком [11, с. 156-158].

Тобто дистанційне навчання $є$ максимально доступним. Однак серйозною проблемою дистанційного навчання $є$ переосмислення використання багатьох перевірених педагогічних прийомів для кращого запам'ятовування і засвоєння матеріалу, наприклад, таких, як: метод опорних точок, метод свідомих помилок, метод вибору кращого рішення та ін.

Методологія дистанційної освіти, усуваючи пасивні методи навчання, активізуючи особистий і діловий досвід слухача, істотно прискорює і поглиблює освоєння необхідних знань і умінь.

Дистанційне навчання створює величезні можливості для ефективного навчання та співпраці поза аудиторією. Перш ніж вивчати різні доступні онлайн-інструменти, важливо мати на увазі наступне:

- у центрі уваги має бути педагогіка та навчання, а не технології;

- у усі інструменти все ще вимагають майстерності, досвіду та досвіду педагога;

- інструменти можуть включати підходи та методи, якими зазвичай педагог не користується;

- $\quad$ інструменти повинні відповідати будь-якій політиці шкільної електронної безпеки;

- суб'єкт-суб'єктна взаємодія «студент-педагог-студент».

Підчас дистанційного навчання виникають реальні побоювання щодо самотності, добробуту та відсутності взаємодії. Важливо знайти спосіб підтримувати контакти з усіма учасниками. Педагог запускає дискусійний форум або групу чатів або ж навчальна платформа. 
Одним із найефективніших способів підтримки дистанційного навчання та навчання $\epsilon$ надання кожному студенту можливості оперувати тематичними знаннями з будь-якої теми. Тобто, можна поділити групу на невеликі групи. Попросити студентів провести семінар та включити онлайн-інструменти для залучення аудиторії. Вони, наприклад, можуть виступити 3 короткою інтерактивною презентацією, що охоплює ключову інформацію, а потім продовжити це онлайн -викликом, щоб зібрати відгуки та оцінити розуміння.

Роль педагога $\epsilon$ ключовою для встановлення та керування навчальними очікуваннями. Однак $\epsilon$ величезна можливість відкрити роботу далі для самих студентів керуючись IT вимогами та інструментами.

Інструменти, що полегшують обговорення та співпращю. Ці інструменти дають можливість педагогам та студентам продовжувати навчання, при цьому підтримуючи існуючі методи навчання, а також даючи можливість відкривати нові способи проведення навчання. Вони включають як синхронні (в режимі реального часу), так і асинхронні (у різні часи) можливості в Інтернеті: Flipgrid, Padlet, Skype Classroom, Kialo, Explain Everything, Educreations.

Інструменти, які дозволяють створювати інтерактивні навчальні вікторини та ігри. Ці інструменти допомагають студентам отримувати задоволення та насолоджуватися досвідом навчання. Це чудові способи залучення віддалених студентів до співпраці в режимі реального часу, використовуючи поставлені вами питання/проблеми. Зокрема, вони можуть навіть використовувати їх для створення власних мікрооцінок, якими можна поділитися 3 іншими в класі: Kahoot!, Socrative, Quizizz, Classcraft.

Інструменти, які дозволяють створювати навчальний контент в Інтернеті. За допомогою цих інструментів можна створювати індивідуальну навчальну діяльність на основі наявного вмісту. Для створення більш складних заходів потрібен час, тому в ідеалі можна інтегрувати їх у існуючий веб -сайт або систему управління навчанням: Adobe Spark, PlayPosit, Quizlet, Canva, Piktochart, Visme.

Формуючі засоби зворотного зв'язку. Ці інструменти дозволяють педагогам вибирати 3 існуючих запитань та ставити завдання оцінювання в режимі онлайн, при цьому, відстежувати прогрес і визначати конкретний навчальний контент, який потребує більшої підтримки: Yасараса, Learning by Questions, Nearpod, Spiral, ClassFlow, Seesaw. 
Створення ідей та вмісту в Інтернеті. Це можливість використовувати онлайн-інструменти для спільного збору різноманітних ідей. Ви можете розпочати це як частину онлайндискусії, а потім попросити дітей виконати іï 3 подальшими завданнями: Coggle, Wakelet, Zotero.

Інструменти опитування/голосування. Ці інструменти дозволяють відстежувати успіхи студентів під час проведення занять в Інтернеті. При цьому педагоги отримують зворотній зв'язок, збирає коментарі та відстежує взаємодію: Crowdsignal, GoSoapBox, Poll, Everywhere.

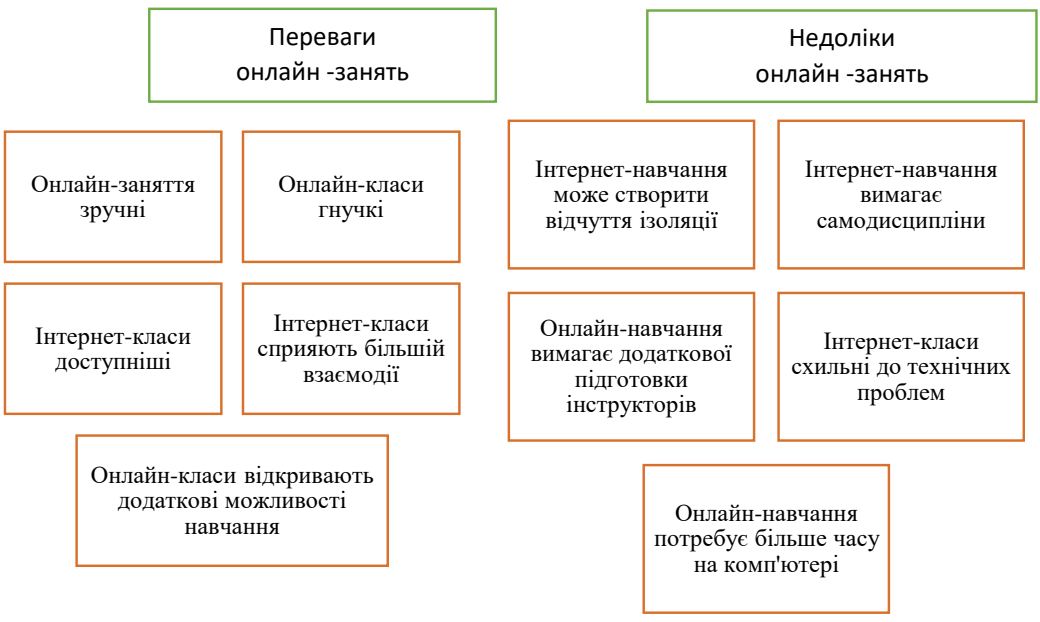

Рис. 10. Переваги та недоліки онлайн-занять

Вищезазначене дає підстави зробити узагальнення про те, що існують переваги та недоліки онлайн-навчання для вищої освіти. Але оскільки технологічні можливості досягли нових висот та вирішують багато основних проблем студентів, які відвідують онлайн-класи, тому переваги онлайн-класів починають заглушувати недоліки.

Офлайн на відміну від онлайн, надає можливість живого спілкування студента та викладача. В онлайні вони можуть вільно спілкуватися один з одним за допомогою віртуальних методів, тобто, це швидше одностороння комунікація між викладачем та студентом. Викладач надсилає студенту матеріали, а студент несе 
відповідальність за набуття необхідних знань для складання іспитів. 3 одного боку, онлайн освіта дає більшу свободу студентам, вони можуть у будь-який час ознайомитися 3 матеріалом та виконати завдання.

Але вона потребує мотивації вчитися самостійно, без будь-яких заохочень від однолітків чи педагогів, щоб проводити їх у матеріалі та пропонувати поради та поради.

Дистанційне навчання вимагає, щоб студенти вміли працювати принаймні з мінімальними знаннями про різні чати, онлайн-іспити та зворотну взаємодію. Обидва варіанти надають різним типам студентам комфортне середовище для отримання нових знань та навичок та задовольняють їхні освітні потреби. це запорука успіху на все життя, особливо для людей, які орієнтуються на кар'єру, які сподіваються просунутися як на особистому, так і на професійному рівні.

\section{3. Дослідження щодо визначення рівня якості викладання навчальної дисципліни «Етнопедагогіка дитинства. Сімейна педагогіка»}

Було проведене дослідження зі студентами КЗВО «Луцький педагогічний коледж» факультету дошкільної освіти та музичного мистецтва, всього було опитано 30 осіб.

Мета цього дослідження полягала у визначенні рівня якості викладання навчальної дисципліни «Етнопедагогіка дитинства. Сімейна педагогіка.». Це дослідження також має на меті дослідити, чи може новатор викладач вплинути на їх готовність до педагогічної діяльності з дітьми, та передбачало авторизацію студентів щодо самооцінки себе та викладача.

Перше запитання було направлене на визначення ефективності інноваційних завдань на перевірку знань, умінь і навичок студентів. Респонденти ранжували варіанти відповідей за запропонованою шкалою: найменш ефективна методика отримувала 1 бал, найбільш ефективна - 7 балів. Учисло перерахованих в анкеті методик увійшли: тестування з вибором варіанти відповіді; тестування без вибору варіанта відповіді; написання есе; тренінги; робота на різних освітніх інтернет платформах.

Відповіді респондентів показали наступні результати: тренінги (погодилося $60 \%$ опитаних); написання есе (погодилося $15 \%$ опитаних); тестування без вибору варіанта відповіді (погодилося $5 \%$ опитаних); тестування з вибором варіанти відповіді (погодилося 
$5 \%$ опитаних); робота на різних освітніх інтернет платформах (погодилося $15 \%$ опитаних).

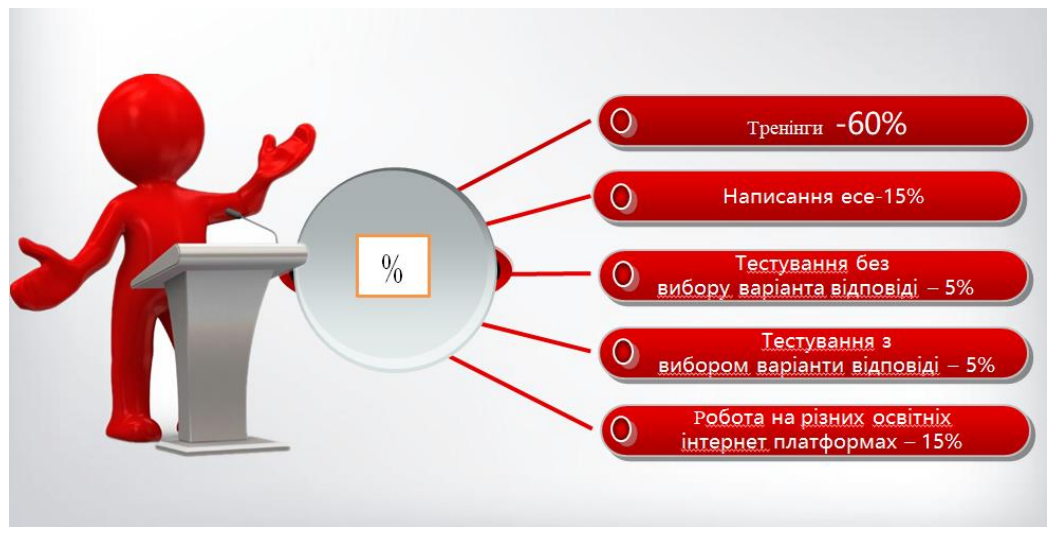

\section{Рис. 11. Результати опитування респондентів}

Такий розподіл методики контролю володіння даною дисципліною, на наш погляд, відображає стримане ставлення до тестування, сформований у сучасних студентів. Респонденти сприймають такий вид роботи як об’єктивну методику перевірки глибини засвоєних знань, але в той же час їм необхідний досвід породження таких тестів для самооцінки себе.

Друге запитання анкети звучало так: «Оцініть наступні завдання на виконання самостійної роботи студента за шкалою від 1 (найменш цікаве завдання) до 10 (найбільш цікаве завдання)». Були запропоновані наступні види

робіт: написання доповідей 3 презентаціями; робота 3 відео ресурсом; командні ігри; складання та демонстрування окремих вправ тренінгів.

Дане запитання було направлено на виявлення у студентів потреб в різноманітності видів інноваційної діяльності в освітньому процесі.

Підсумки результатів ранжування видів самостійної діяльності студентів можна відобразити наступним чином: робота 3 відеоресурсом (погодилося 10\% опитаних); написання доповідей 3 презентаціями (погодилося $5 \%$ опитаних); командні ігри (погодилося $10 \%$ опитаних); складання та демонстрування окремих вправ тренінгів (погодилося 75\% опитаних); 


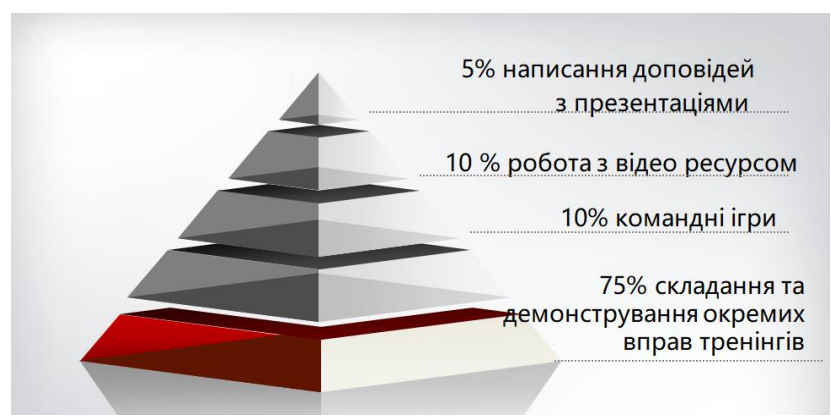

\section{Рис. 12. Результати опитування респондентів}

Респонденти (20\%) повідомили, що викладач викладає на достатньому рівні, а решта представляє високу шкалу (80\%). Серед основних характеристик, студенти зазначали, що курс був на оснащений літературними джерелами у підготовці до семінарів. Лекції: велика кількість актуальної інформації, відео завдання, пояснення + до кожного семінару викладач надсилав дуже детальний перелік запитань, визначень тощо, що ми маємо знати з цієї теми + перелік рішень і всього, що треба при цьому перелік складений таким чином, що не [підготувавшись], не зможеш вирішити завдання, а це виключало халтуру. Практичні інноваційні кейси. Пояснення теоретичного матеріалу на практиці. Наведення реальних кейсів 3 життя. Цікаві лекції у вигляді тренінгів, добре викладений матеріал, додаткова література при підготовці до семінару дійсно зацікавила та зробила підготовку до нього справді необтяжливою. Практичні заняття були продуктивними іта стосувалися саме мети курсу.

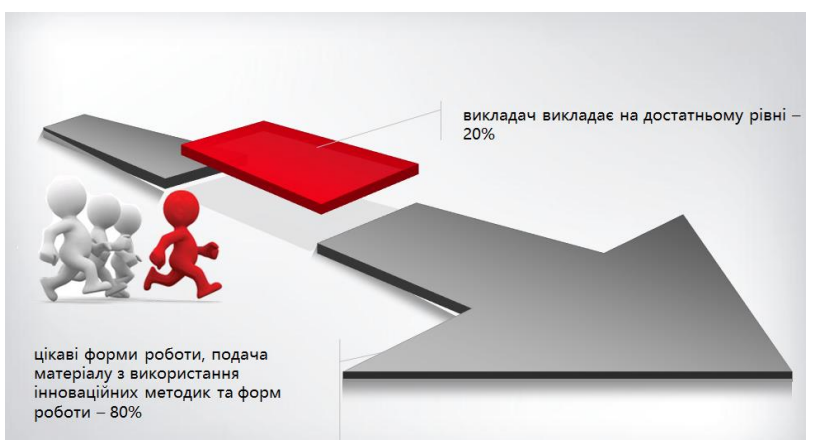

Рис. 13. Результати опитування респондентів 
Таким чином, моніторинг інтересу до різних видів контролю знань у студентів показав, що найбільш затребуваними формами діяльності $\epsilon$ завдання, сконструйовані інтерактивно, де присутні нові технології.

Примітно й те, що командні види роботи також викликали інтерес в студентів. Зокрема, вони зазначали, що «творчі завдання, розвивали у них окремі можливості креативності». Це говорить про потребу студентів у спільній рефлексії результатів навчання, при якій знижується рівень психологічного тиску.

Далі ми досліджували інтерес студентів до тематичного наповненню професійного блоку дисциплін.

Третє запитання анкети була відкритим: «Як би Ви хотіли вивчити дисципліну «Етнопедагогіка дитинства. Сімейна педагогіка?».

Для додаткової мотивації студентів до активної участі в засвоєнні даного курсу практичні заняття готувалися і проводилися за методикою колективної творчої діяльності. Використання даної технології необхідно майбутнім вихователям закладів дошкільної освіти, гувернерам для ефективної організації групових занять. Реалізація даної технології припускала розбивку навчальної групи на мікрогрупи 3-4 осіб. Студенти (10\%) зазначали, що хотіли б самостійно шукати теми занять, $10 \%$ наполягали на тому, що підібрати питання і організувати дискусію потрібно за визначеними темами занять, за які та чи інша група була відповідальною, 15\% наполягала на практичному використанні набутих знань та умінь. Спочатку в обговоренні, а потім застосуванні конкретних інноваційних технологій у порівнянні з традиційними вправами можливостями фольклорних, ігрових та інших етнопедагогічних джерел.

$65 \%$ респондентів наполягали на створенні «Педагогічної майстерні», що передбачає безпосередню передачу викладачем досвіду використання інноваційних технологій студентам («з рук в руки») та їх апробацію в ході занять. Ці заняття були орієнтовані на комплексне (теоретичне та практичне) засвоєння провідних етнопедагогічних джерел, засобів, технологій, засвоєння правил їх застосування в практиці роботи педагога в сім'ї. Так звані посиденьки на такій майстерці готувалися творчим мікроколективом по 4-5 осіб. Усередині якого розподілялися обов'язки: підготовка основного виступу за темою, що стосуються використання інноваційних технолог в педагогічній діяльності; підбір запитань, завдань для організації дискусії на тему заняття; 
підготовка та проведення ділової гри чи тренінгу з використання однієї з інноваційних технологій у конкретних ситуаціях.

Мікроколективу, ведучому заняття, давалася установка щодо забезпечення повноцінної мотивації освоєння технологій кожним студентом, розвитку первинних умінь її застосування в педагогічній діяльності.

Кожне заняття включало ряд обов'язкових етапів: оголошення теми та мети заняття (Canva, Powerpointbase); мотивація вивчення теми, попереднє опитування (Kahoot, На урок, Всеосвіта); основна частина (mind map); проведення дискусії (workshop). у ході занять використовувалися традиційні та інтерактивні методи навчання: лекція, бесіда, пояснення, ділові та рольові ігри, тренінги, дискусії та ін.

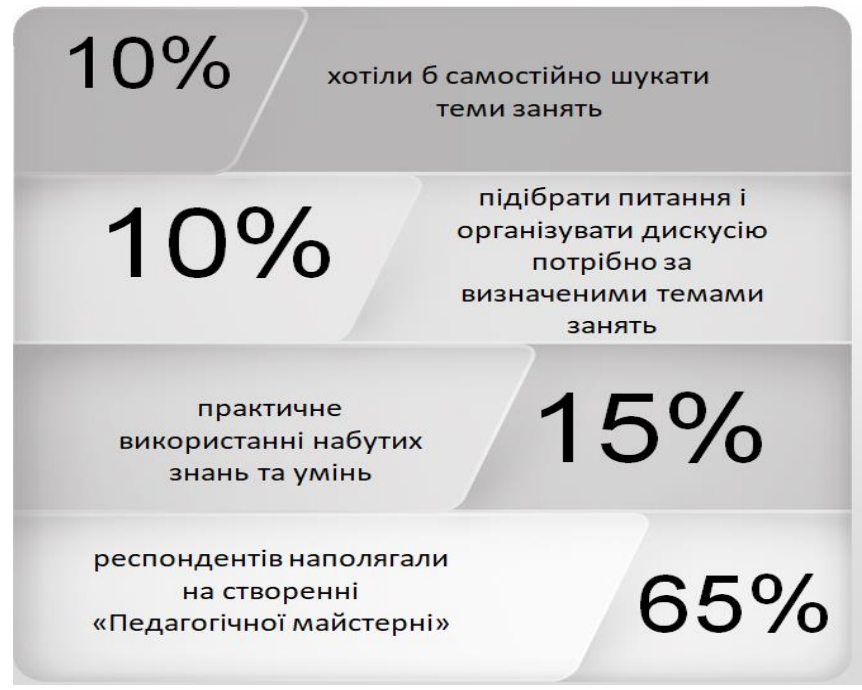

Рис. 14. Результати опитування респондентів

Отже, дослідження показало, що втрата часу для студента коли викладач пропонує спокійно посидіти (опустивши голову) i продовжувати займатися своїми справами, такими як перевірка паперів тощо. Але сучасний викладач може запитати: Чому б вам не навчити мене чогось на цю тему? I це дозволяє студентам переглядати речі, при цьому пояснюючи деякі теми. I викладач щасливий дізнатися щось нове від них. Це нормально - не бути експертом з даної теми, щоб розпочати навчальне середовище. 
Сучасний викладач може попросити студентів запропонувати свої пропозиції щодо самовдосконалення, щоб могли спробувати навчитися з інших джерел. Замість того, щоб боятися змін, сучасні педагоги відчувають радість від викликів та пригод, які технології та інновації приносять освіті. Вони готові вийти зі своєї зони комфорту. Сучасний викладач заохочує спільне навчання, де слабкі студенти можуть навчатися співіснувати в оновленому інноваційному освітньому середовищі.

\section{Висновки}

Таким чином, перед викладачами стоїть завдання створити освітнє середовище, так, щоб цікаво було студентам здобувати свою спеціалізацію у закладі вищої освіти. Ці шляхи вимагають значного професійного навчання з боку викладачів. Перевага буде в тих, хто набуває професійного розвитку для інтеграції мобільного навчання зі студентами за допомогою інтерактивних методів та технологій.

Для студентів дуже подобається захоплююча ідея запуску інноваційних технологій в освітній процес викладання викладачем навчальних дисциплін. Але перш ніж перейти до таких інновацій, викладач повинен точно знати, яка корпоративна інноваційна модель побудови освітньої програми підходить саме йому. Ми часто бачимо, як запроваджуючи щось нове прослідковується відсутність згуртованості, коли справа доходить до практичних способів, якими стартапи можуть врешті -решт підкреслити ваш результат.

Усі успішні інноваційні моделі освітнього середовища закладу вищої освіти починаються в одному місці: будується стратегія навколо того, чого хоче досягти в майбутньому студент. Важливо пам'ятати, що інновації - це не те, що виходить «з коробки»; вони різні для кожного потоку студентів.

Частиною освітнього інноваційного процесу, коли ми розгортаємо одну з наших програм, $\epsilon$ пошук нового партнера-студента, з яким це можна зробити. Однак місія викладача полягає в тому, щоб завжди існувала партнерська суб'єкт-суб'єктна взаємодія «студентвикладач-студент», при цьому гарантуючи успіх та інтелектуальний розвиток особистості. Тому, студенти хочуть бачити сучасного викладача (гнучкий, мобільний, інтелектуальний, творчий, креативний, само досконалий). Педагоги, які розуміють своїх студентів та адаптуються з часом, роблять великий вплив на процес розвитку освіти, ставлячи нові орієнтири для інших. 


\section{Література}

1. Інноваційні технології навчання : навч. посібн. для студ. вищих технічних навчальних закладів / кол. авторів ; відп. ред. Бахтіярова Х.Ш. ; наук. ред. Арістова А.В. ; упорядн. словника Волобуєва С.В. К. : НТУ, 2017. 172 с.

2. Експериментальна психологія : курс лекцій / уклад. О.В. Романенко. К. : Нац. акад. внутр. справ, 2017. 146 с.

3. Загашев I. Нові педагогічні технології в шкільній бібліотеці: освітня технологія розвитку критичного мислення засобами читання та письма. URL: https://lib.1sept.ru/2004/17/15 (дата звернення 20.09.2021).

4. Халперн Д. Психология критического мышления. СПб. : Питер, 2000. 512 c.

5. Архіпова $€$. О. Критичне мислення як необхідна складова розумової діяльності людини в межах сучасного інформаційного суспільства. Гуманітарний часопис. 2012. № 2.

6. Шеннон О'Коннелл, Абдул Салам Медені Посібник для тренера: Як підготувати та провести тренінг, що матиме вплив https://www.ndi.org/sites/default/files/Manual\%20for\%20trainers (дата звернення 20.09.2021).

7. Захист дитини від насильства та жорстокого поводження: сучасні виклики : матеріали Міжнар. наук.-практ. конф. (Київ, 3 черв. 2021 р.) / редкол.: В. В. Чернєй, С. Д. Гусарєв, С. С. Чернявський та ін. Київ : Нац. акад. внутр. справ, 2021. С. 58-61.

8. Інтерактивні форми і методи навчання у вищий школі : навч.метод. посіб. / В. В.Ягоднікова. К.: ДП «Вид. дім «Персонал», 2009. $80 \mathrm{c}$.

9. Нісімчук А.С., Падалка О.С., Шпак О.Т. Сучасні педагогічні технології : навчальний посібник. К. : Видавничий центр «Просвіта», 2000. C. 219.

10. Замелюк М. Формування готовності майбутнього вихователя до розвитку творчого потенціалу дошкільника засобами авторської казки : автореф. дис. ... канд. пед. наук : 13.00.04; Кременчуц. нац. ун-т ім. Михайла Остроградського. Кременчук, 2017. 20 с.

11. Замелюк М. Інновації у фаховій підготовці майбутнього педагога дошкільної освіти. Актуальні проблеми педагогічної науки : зб.матеріалів IV Всеукраїнської науково-практичної заочної конференції. Миколаїв. 2013. С. 159-158. 